\title{
PKM Pendampingan Strategi Usaha Mikro dan Kecil Menengah Batik Dewi Rengganis untuk Meningkatkan Ekonomi Keluarga dan Daya Saing
}

\author{
Muh Hamzah¹, Rusida², Silviana Devi ${ }^{3}$, Husnul Khotimah4,
} Tartila ${ }^{5}$, Nurul Isma ${ }^{6}$, Wildatul Aluf ${ }^{7}$

Universitas Nurul Jadid, Probolinggo ${ }^{1,2,3,4,5,6,7}$

\{hamzah.stikesnj@gmail.com\}

\begin{tabular}{ll} 
Submission: 09/10/2021 Received: 31/12/2021 Published: 31/12/2021 \\
\hline $\begin{array}{l}\text { Keywords: } \\
\text { Accompaniment, }\end{array}$ & (MSMEs) in the national economic map is very important. This is \\
Marketing & because of its great role in stemming the economic and social \\
Strategy, UMKM & problems of society, such as poverty, unemployment, and so on. In \\
Batik Dewi & addition, another function that cannot be ignored is community \\
Rengganis & empowerment. This function is carried out well by MSME Batik \\
& Dewi Rengganis. This MSME is a source of economic greeting for \\
& women who live around the home industry. This assistance is \\
& transformative-participatory using a Participatory Action Research \\
& approach. During the mentoring process, the following points were \\
& obtained that the strategy used to improve the economy of the \\
& sutik galleries is not only a means of marketing products, but also \\
& as a means of educational tourism for the community, 3). Has a \\
& variety of motifs and patterns, and 4). Always innovate and be \\
& creative. In addition, several things that need to be improved are \\
& how to develop the capabilities of human resources and technology \\
& by, for example, involving several existing human resources in \\
& training activities, counseling, and workshops on batik and \\
information technology, as well as providing adequate access to \\
marketing
\end{tabular}

Katakunci:

Pendampingan,

Strategi

Pemasaran,

UMKM Batik Dewi

Rengganis

\begin{abstract}
Abstrak. Posisi usaha mikro dan kecil menengah (UMKM) dalam peta ekonomi nasional sangat penting. Hal ini karena perannya yang besar dalam membendung masalah-masalah ekonomi dan sosial masyarakat, seperti persoalan kemiskinan, pengangguran, dan lain sebagainya. Selain itu, fungsi lainnya yang tidak bisa diabaikan ialah pemberdayaan masyarakat. Fungsi ini dijalankan dengan baik oleh UMKM Batik Dewi Rengganis. UMKM ini menjadi salam satu sumber ekonomi bagi perempuan-perempuan yang tinggal di sekitar home industry tersebut. Pendampingan ini bersifat tranformatif-partisipatoris dengan menggunakan pendekatan Participatory Action Research. Selama proses pendampingan berlangsung diperoleh beberapa hal berikut bahwa strategi yang digunakan untuk meningkatkan ekonomi masyarakat sekitar ialah dengan a). memberdayakan kaum perempuan, 2). Membuat galeri batik tidak hanya sebagai sarana memasarkan
\end{abstract}


produk, namun juga sebagai sarana wisata edukasi bagi masyarakat, 3). Memiliki motif dan corak yang beranekaragam, dan 4). Selalu berinovasi dan berkreasi. Selain itu, beberapa hal yang perlu ditingkatkan adalah bagaimana mengembangkan kemampuan sumber daya manusia dan teknologi dengan misalnya mengikutsertakan beberapa SDM yang ada dalam kegiatankegiatan pelatihan, penyuluhan, maupun workshop tentang batik dan teknologi informasi, serta menyediakan akses pemasaran yang memadai.

\section{Pendahuluan}

Usaha Mikro dan Kecil Menengah (UMKM) mempunyai andil yang sangat stategis dalam peningkatan ekonomi nasional, di samping itu pula ia mempunyai peran dalam menopang keberlangsungan ekonomi keluarga, utamannya pengelola, karyawan yang bekerja di dalam UMKM tersebut. Dengan kata lain, pengelolaan UMKM dapat menjadi salah satu pendorong perekonomian suatu bangsa (Kusumawardhani \& Nurani, 2019). Hal ini terbukti bahwa sentra bisnis Batik di Jawa sudah menjadi andalan pendapatan daerah yang utama dan menjadi penggerak ekonomi masyarakatnya, seperti di Yogyakarta, Solo, Pekalongan maupun daerah lainnya (Dewanti et al., 2013).

UMKM dapat terbentuk dan terwujud di tengah-tengah masyarakat, jika setidaknya kondisi sosial masyarakat terdapat unsur-unsur sebagai berikut (Pranarka, 1996):

a. Pengetahuan masyarakat; pengetahuan, gagasan, ide, ataupun konsep sangat menentukan jenis maupun bentuk dari UMKM yang diinginkan. Pengetahuan ataupun gagasan ini umumnya dapat diperoleh melalui pengalaman masyarakat itu sendiri.

b. Kemandirian masyarakat; kemampuan masyarakat untuk merubah nasibnya sendiri dengan kekuatan yang dimilikinya, baik kekuatan untuk mengelola sumber daya alam maupu sumber daya manusia yang ada pada lingkungan masyarakat itu sendiri maupun kemampuan untuk meminimalisir ketergantuan, dalam hal ini ketergantungan ekonomi dari pihak lain.

c. Aktualisasi diri; hal ini berkaitan dengan kemampuan individu untuk menampilkan potensi yang ada pada dirinya dan/atau kemampuan untuk melihat peluang yang ada di sekitarnya yang berguna baik untuk kepentingan dirinya maupun kepentingan bersama. 
Jika ketiga unsur di atas terdapat pada kondisi sosial masyarakat tertentu, maka akan lahir sikap kemandirian, peningkatan kreativitas dan inovasiinovasi baru, serta kemampuan untuk menyampaikan permasalahan yang dihadapi. Sekalipun kondisi ekonomi nasional berada dalam posisi buruk, seperti kondisi pertumbuhan ekonomi dunia maupun nasional yang krisis menghadapi pandemi covid-19.

Pandemi covid-19 yang menimpa Indonesia sejak awal bulan Maret 2020 membuat ekonomi masyarakat lumpuh, tidak berdaya, dan tidak berkembang, banyak di antaranya gulung tikar karena nilai permintaan konsumen semakin rendah dari sebelumnya. Hal ini juga dialami oleh UMKM Batik Dewi Rengganis Desa Jatiurip Kecamatan Krejengan Kabupaten Probolinggo (untuk selanjutnya kami sebut Batik Dewi Rengganis). Batik Dewi Rengganis hampir saja mengalami kebangkrutan, karena minimnya permintaan konsumen terhadap produknya, akan tetapi ia mampu bertahan karena keunggulan dan kekhasan yang dimilikinya. Adapun ciri khas atau karakter yang menjadi keunggulan dari produksi batik ini adalah penggunaan Lambang Dewi Rengganis yang terinspirasi dari legenda Dewi Rengganis yang konon pernah bersentuhan dengan budaya sosial masyarakat Probolinggo (Wati et al., 2013). Dijelaskan, ia merupakan salah seorang putri dari Prabu Brawijaya, Raja Majapahit, yang lahir dari salah satu selirnya. Konon Putri ini, pernah tinggal di antara Kecamatan Krucil, Tiris dan Krejengan.

Terlepas dari historisitas Dewi Rengganis, Batik Dewi Rengganis didirikan oleh Hj. Rusyami pada tahun 2004. Ia mendirikan home industry Batik Dewi Rengganis karena kejenuhan dan waktu luangnya sebagai ibu rumah hanya dihabiskan dengan berdiam diri di rumah. Sehingga beliau berinisiatif dan bertekad untuk melakukan perubahan, tidak hanya untuk dirinya sendiri melainkan juga untuk masyarakat sekitarnya. Atas tekad kuatnya tersebut, maka lahirnya home industry Batik Dewi Rengganis melalui kegiatan pemberdayaan perempuan di Desa Jatiurip. Tujuan utamanya adalah untuk membantu ekonomi kaum perempuan di sekitarnya (Widyasari et al., 2021). Batik Dewi Rengganis ini kemudian dikenal oleh masyarakat luas sejak diresmikan sebagai batik khas Kabupaten Probolinggo oleh bupati setempat pada tahun 2017 yang pada waktu itu telah memiliki 34 karyawan yang bekerja di dalamnya. Saat ini home industry tersebut telah memiliki 48 karyawan yang mayoritas adalah kaum perempuan. 
Dengan memperhatikan ulasan singkat mengenai Batik Dewi Rengganis di atas, maka penting untuk diketahui strategi apa saja yang digunakan untuk melestarikan dan meningkatkan jumlah penjualan Batik Dewi Rengganis tersebut sehingga mampu menopang perekonomian banyak keluarga yang bekerja di dalam home industry tersebut. Selain itu juga penting untuk dilakukan pembinaan kepada UMKM Batik Dewi Rengganis agar mampu bersaing baik di tingkat nasional maupun internasional. Mengingat kegiatan apapun, terlebih di bidang ekonomi, tanpa mau menerima saran, masukan, bantuan, bahkan kritikan dari orang lain, akan sulit untuk maju dan berkembang.

\section{Metode}

Program pendampingan ini ditujukan untuk seluruh karyawan UMKM Batik Dewi Rengganis yang berjumlah 48 orang. Pelaksanaan pendampingan ini dilakukan dengan tetap mematuhi protokol kesehatan dan berlangsung selama 3 bulan mulai dari bulan Februari 2021 hingga bulan April 2021 dengan melibatkan 8 orang mahasiswa aktif dari Universitas Nurul Jadid, Paiton Probolinggo.

Pendampingan ini bersifat tranformatif-partisipatoris, yakni bagaimana mentransformasikan beberapa strategi ekonomi guna meningkatkan ekonomi keluarga sekaligus menciptakan perubahan positif di lingkungan mereka. Oleh karena itu, pendekatan yang sesuai untuk diterapkan dalam program pendampingan ini ialah Participatory Action Research (PAR); selain melibatkan seluruh peserta dampingan, pendamping juga dituntut untuk berpartisipasi dalam setiap kegiatan yang dilaksanakan, sehingga tujuan yang diharapkan dapat tercapai.

\section{Hasil dan Pembahasan}

\section{Strategi UMKM Batik Dewi Rengganis dalam Meningkatkan Ekonomi Keluarga}

UMKM Batik Dewi Rengganis yang berada di Desa Jatiurip Kecamatan Krejengan Kabupaten Probolinggo ini memiliki beberapa strategi pemasaran 
guna meningkatkan ekonomi masyarakat yang bekerja di dalamnya. Di antara beberapa strategi tersebut adalah sebagai berikut;

1. Pemberdayaan kaum perempuan
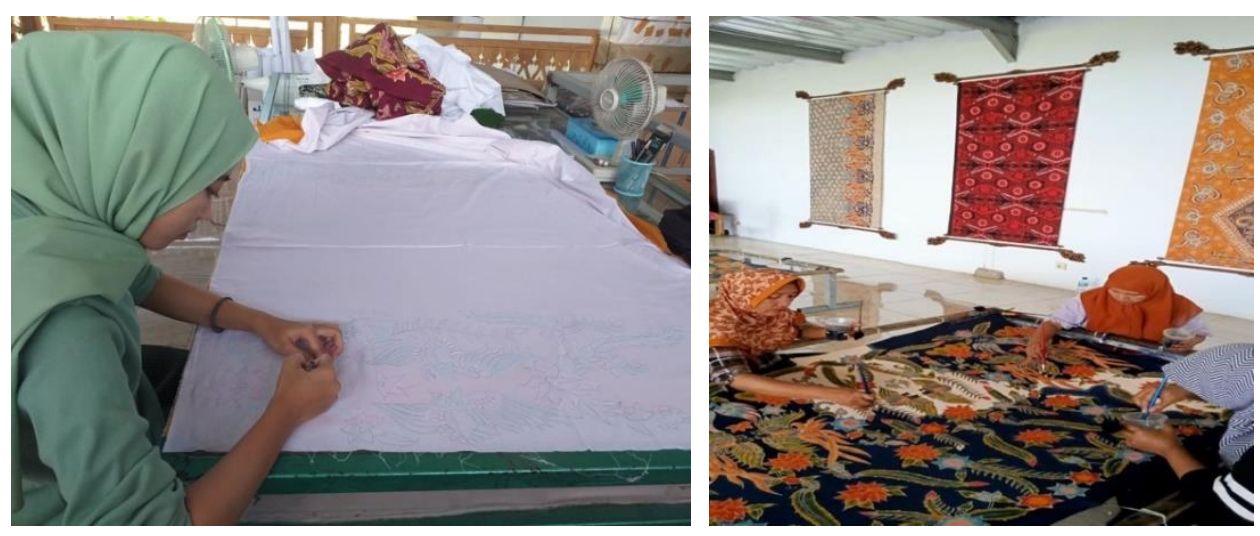

Pendiri UMKM Batik Dewi Rengganis sengaja membidik kaum perempuan di sekitar rumahnya karena beberapa hal, antara lain; menurut Hj. Rusyami menjadi ibu rumah tangga dengan hanya berdiam diri di rumah tanpa ada aktivitas apapun, itu sangat membosankan. Beliau juga ingin kaum perempuan di desanya tidak hanya produktif tetapi juga mampu menambah pendapatan keluarganya (Widyasari, 2018).

Salah satu karyawan perempuan yang telah lima (5) tahun bekerja di UMKM Batik Dewi Rengganis menyatakan bahwa selama belajar dan ikut serta dalam kegiatan membatik di UMKM Batik tersebut, sangat bersyukur karena di samping memiliki bekal dan pengetahuan tentang hal yang berkaitan dengan batik, mulai dari cara membuat batik yang berkualitas hingga motif-motif batik yang bernilai tinggi, juga dapat membantu finansial ekonomi keluarganya. Hal senada juga di sampaikan oleh beberapa teman perempuan lainnya, bahwa keberadaan UMKM Batik Dewi Rengganis sangat bermanfaat bagi dirinya dan keluarganya, dari yang sebelumnya hanya berpangku tangan pada suami, kini mereka lebih produktif baik dalam bekerja maupun berkarya. 
2. Adanya Galeri Batik Dewi Rengganis

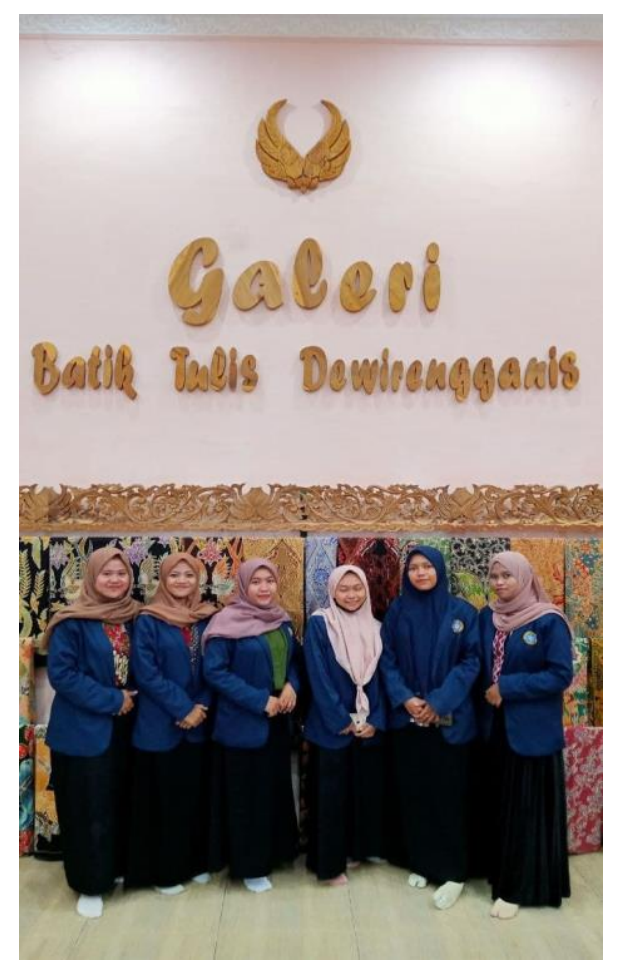

Galeri Batik Dewi Rengganis diresmikan oleh Bupati Probolinggo Hj. Puput Tantriana Sari, SE pada Rabu 11 Oktober 2017 yang lalu. Harapan Ibu Hj. Rusyami selaku pendiri galeri tersebut adalah untuk meningkatkan minat wisata enterpreneur di kalangan masyarakat dari berbagai lapisan. Hal ini tentu sekaligus bagian dari strategi yang akan dapat meningkatkan jumlah penjualan batik Dewi Rengganis, mengingat cukup banyak orang yang telah maupun masih akan berkunjung ke galeri tersebut, baik hanya untuk sekedar berkunjung maupun ingin belajar lebih jauh tentang teknik maupun prospek batik tulis di masa depan (Puput, 2017).

Tidak semua pengusaha batik memiliki galeri batik seperti yang dimiliki oleh UMKM Batik Dewi Rengganis. Galeri Batik Dewi Rengganis tidak hanya digunakan untuk memamerkan dan menjual beragam jenis motif batik yang telah diproduksi, melainkan juga dijadikan sebagai sarana wisata edukasi bagi masyarakat, khususnya kawula muda untuk belajar mengenai batik sebagai warisan budaya Indonesia. 
Beberapa orang yang datang ke galeri tersebut menyatakan kegembiraannya bahwa selama berada di dalam galeri batik mereka sangat senang karena selain bisa belajar tentang batik, juga dapat memperoleh batik favoritnya dengan harga yang sangat terjangkau. Hal ini menunjukkan bahwa keberadaan galeri batik bagi UMKM Batik Dewi Rengganis menjadi berkah tersendiri, selain dapat menyalurkan ilmu pengetahuan tentang batik kepada masyarakat luas, juga dapat meningkatkan jumlah omzet dan penjualan batik.

\section{Corak batik yang beragam}

Batik Tulis Dewi Rengganis merupakan salah satu dari tiga pioner pengrajin batik tulis di Kabupaten Probolinggo, Jawa Timur. Hasil batiknya dari segi kualitas dan kuantitas memang tidak perlu diragukan lagi, bahkan, konsistensi dan eksistensinya dalam menginspirasi sesama insan batik di Kabupaten Probolinggo dalam berkarya itu masih terjaga hingga saat ini (Sari \& Susanti, 2019).

Batik Dewi Rengganis sendiri memiliki ciri khas serta keunikan motif yang berbeda dengan motif-motif batik lainnya, dimana pada setiap motif batik tersebut menceritakan sosok sang Dewi Rengganis. Beberapa motif tersebut antara lain Rengganis Kelayu, Rengganis Kasmaran, Pengasihan Dewi Rengganis, Wijaya Kusuma, Panji Laras, dan Sayap Ratu. Beberapa gambar dari berbagai jenis motif tersebut dapat dilihat pada gambar berikut:

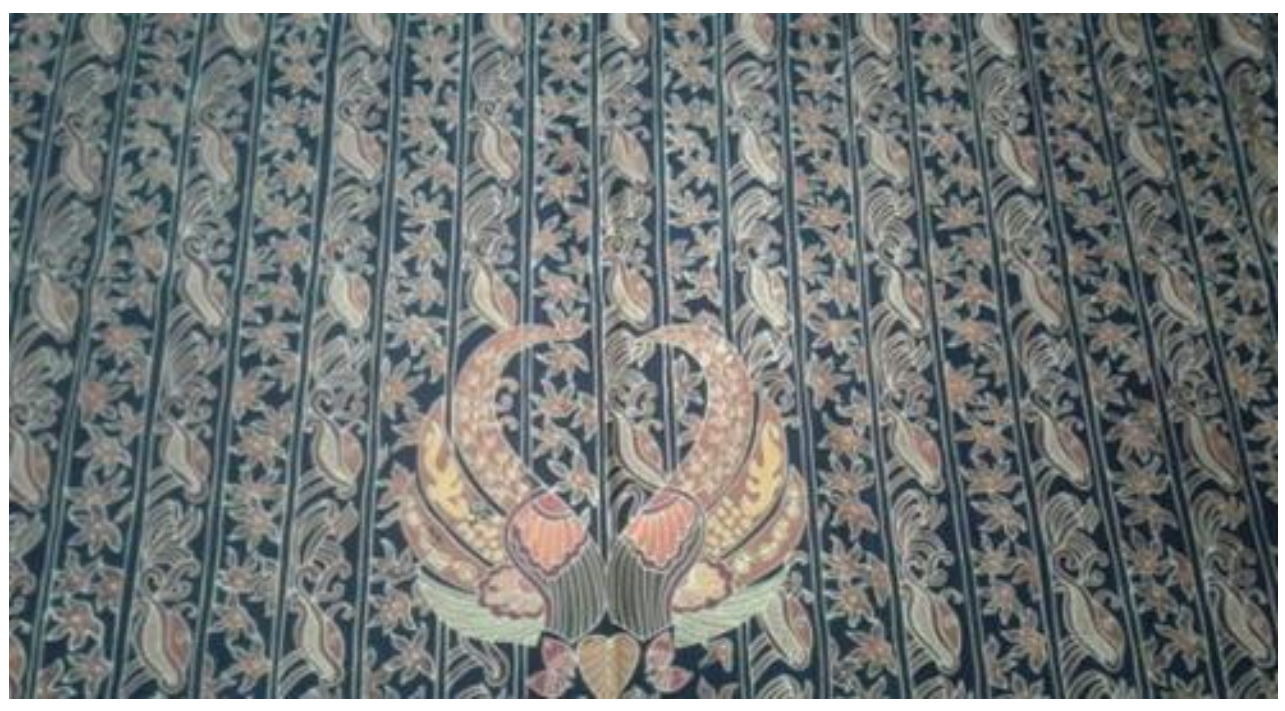

Gambar 2. Motif Pengasihan Dewi Rengganis 
Motif Pengasihan Dewi Rengganis mengisahkan sifat penyayang dari Dewi Rengganis yang terpotret dalam bentuk mahkota. Warna biru yang menjadi warna background menjadi pertanda betapa dalamnya rasa kasih sayang sang Dewi. Terdapat pula gambar daun dan sulur yang menandakan kekuatan yang menyatu dalam kasih sayang.

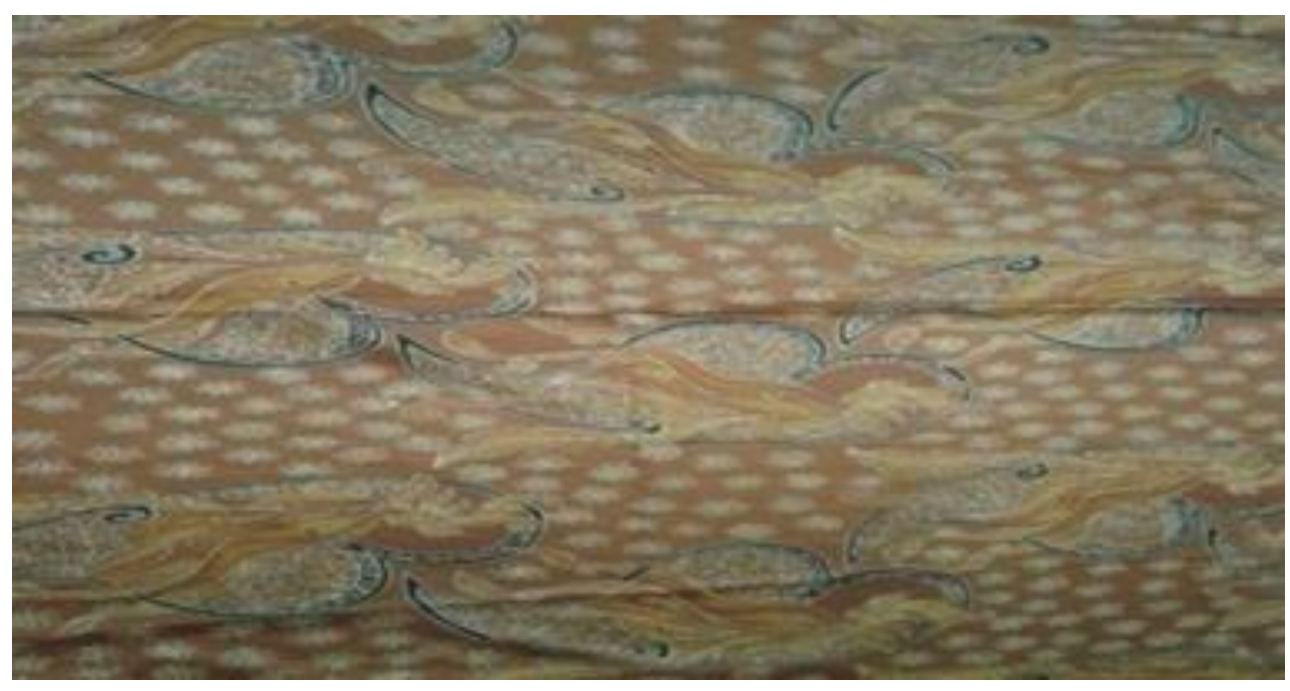

Gambar 4. Motif Rengganis Kasmaran

Motif Rengganis Kasmaran sesuai dengan namanya menyajikan tentang kisah cinta sang Dewi, sehingga diibaratkan dalam bentuk hati dengan panah yang menusuk jantung Dewi Rengganis. Selain itu, terdapat pula gambar sang Dewi yang melayang-layang seakan ia terlena akan panah cinta tersebut. 


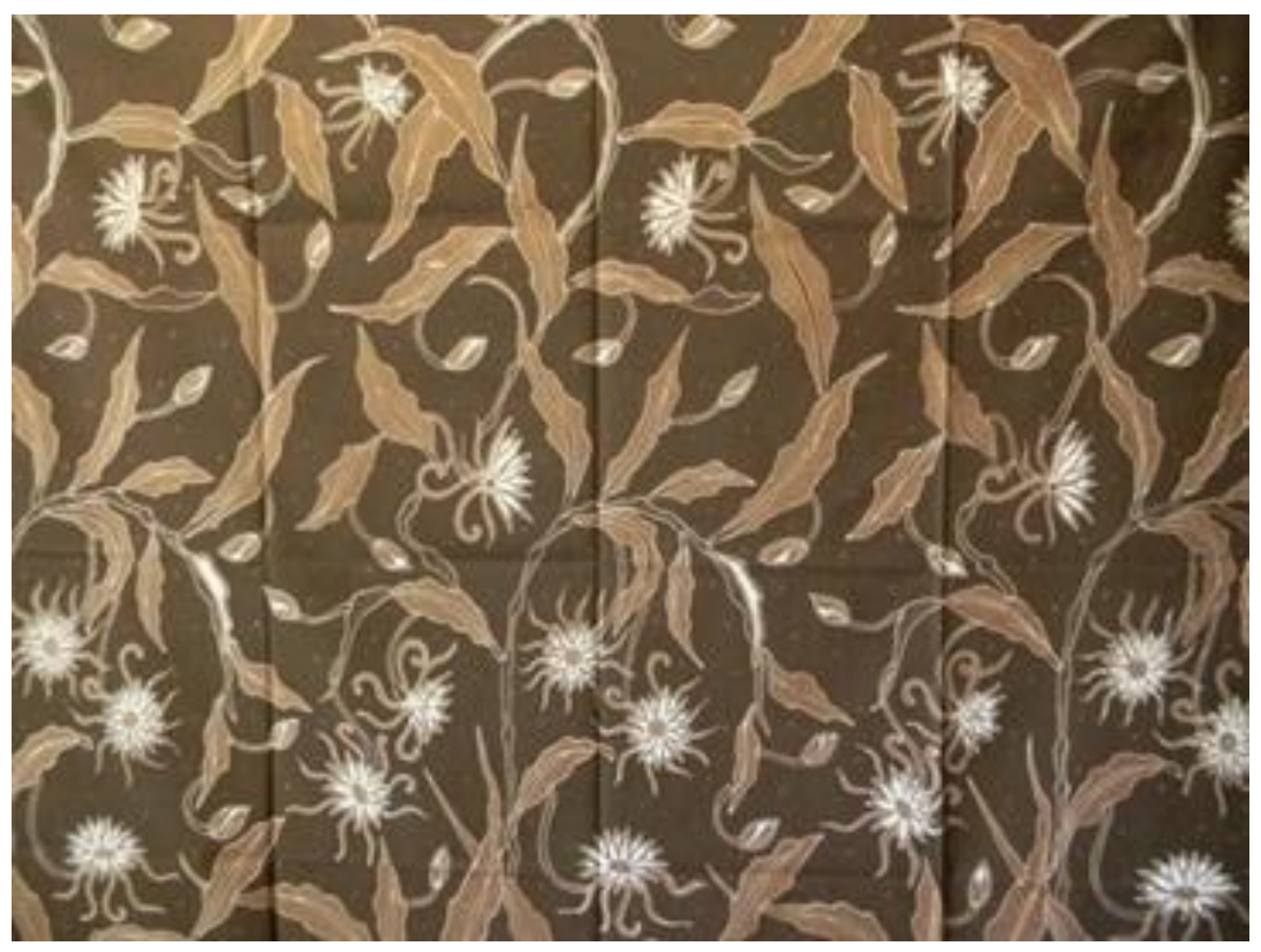

Gambar 5. Motif Wijaya Kusuma

Motif Wijaya Kusuma menyiratkan beberapa mitos bahwa bunga wijaya kusuma memiliki kaitan yang cukup erat dengan raja-raja pada kerajaan Majapahit. Pada masa itu, setiap orang yang menjadi calon raja harus bisa mengambil dan memetik bunga wijaya kusuma yang mekar sebelum mereka naik tahta. Hal ini karena ritual tersebut dipercaya akan mendatangkan kejayaan baginya tatkala memimpin kerajaan. Selain itu, siapapun yang dapat memiliki dan menanam bunga wijaya kusuma, maka dirinya dan keluarganya akan mendapatkan keuntungan yang besar.

Dibalik beragam motif yang dimiliki oleh UMKM Batik Dewi Rengganis tersebut, ternyata hanya beberapa motif yang menjadi masterpiece dan sangat laris dipasaran, yaitu motif Pengasihan Dewi Rengganis dan motif Wijaya Kusuma. Meski demikian, bukan berarti motif-motif batik yang lain tidak laku di tengah-tengah masyarakat. Karena semakin banyak motif yang diproduksi, maka akan semakin banyak pilihan yang sesuai dengan selera masing-masing individu masyarakat. Hal terbukti dengan semakin 
meningkatkan omzet yang diperoleh oleh UMKM Dewi Rengganis tiap bulannya.

4. Inovasi dan kreativitas yang tinggi

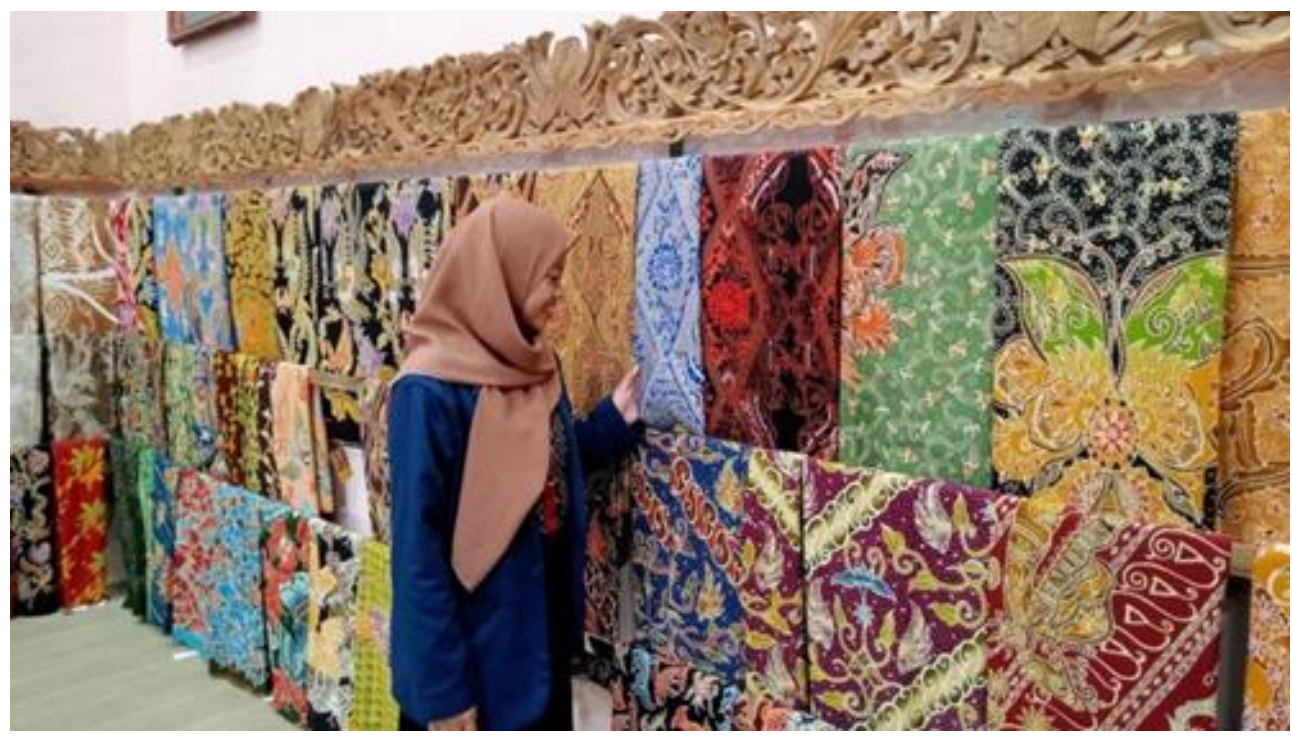

Strategi lainnya yang tidak kalah penting dalam dunia usaha adalah kemampuan untuk berinovasi dan berkreasi. Luasnya networking (jaringan) hanya merupakan salah satu kunci kesuksesan suatu usaha. Tanpa adanya inovasi dan kreativitas, sebuah usaha akan stagnan, terlebih di era teknologi digital seperti saat ini. Hal inilah yang selalu ditekankan oleh pendiri UMKM Batik Dewi Rengganis kepada setiap karyawannya bahwa perempuan itu harus mampu berkreasi dan berinovasi, serta harus bisa lebih tangguh dari laki-laki. Pernyataan tersebut dibuktikan oleh seluruh karyawannya dengan melahirkan kreasi dan inovasi baru yang sangat memukau mata setiap konsumen sebagaimana terlihat pada gambar di atas.

Dengan inovasi dan kreativitas yang tinggi, maka sebuah usaha akan semakin dikenal di masyarakat. Semakin populer sebuah produk di masyarakat, maka akan semakin meningkatkan penjualan produk tersebut. Seperti misalnya bagaimana kemasan produk tertentu mampu mempengaruhi mata konsumen untuk membeli produk tersebut ataupun tidak (Apriyanti, 2018). 


\section{Pendampingan UMKM Batik Dewi Rengganis dalam Meningkatkan Ekonomi Keluarga dan Daya Saing}

Pendampingan ini dilakukan melalui pelaksanaan kegiatan seminar tentang peran UMKM Batik Dewi Rengganis dalam meningkatkan perekonomian keluarga dan meningkatkan daya saing di Pasar Global pada 15 Maret 2021 yang diselenggarakan oleh Tim KKN UNUJA dengan mendatangkan pakar atau ahli di bidangnya. Beberapa poin yang disampaikan pemateri dalam kegiatan tersebut tersaji dalam paparan berikut;

Bahwa UMKM adalah kegiatan ekonomi yang dilakukan oleh masyarakat dengan cara swadaya mengelola sumber daya apa saja yang dimiliki dan dapat dikuasai serta ditujukan untuk memenuhi kebutuhan dasarnya dan kebutuhan keluarganya (Mubyarto et al., 1996). Dengan demikian, UMKM dapat dikatakan sebagai salah satu kegiatan ekonomi yang memiliki peran penting dalam menopang ekonomi masyarakat. Semakin banyak UMKM berdiri, maka semakin baik pula ekonomi masyarakat, hal ini dikarenakan masalah kemiskinan, pengangguran, dan masalah-masalah sosial lainnya dapat berkurang. Selain itu, masyarakat juga akan semakin berdaya, memiliki sikap mandiri, dan semakin terasah kreativitasnya. Terlebih setelah diundangkannya UU No 11 Tahun 2020 tentang Cipta Kerja yang berdampak positif bagi keberadaan dan keberlansungan UMKM di Indonesia, di mana perizinan untuk pelaku UMKM cukup hanya dengan melakukan pendaftaran saja (Rizal, 2021). Selain itu, pelaku usaha dan UMKM juga akan mendapatkan beberapa manfaat yang meliputi:

1. Kemudahan dan kepastian dalam mendapatkan perizinan berusaha

2. Pemberian hak dan perlindungan pekerja/buruh yang dapat dilakukan dengan baik, akan meningkatkan daya saing dan produktivitas

3. Mendapatkan insentif dan kemudahan, baik insentif fiscal maupun kemudahan dan kepastian pelayanan dalam rangka investasi

4. Adanya ruang kegiatan usaha yang lebih luas, untuk dapat dimasuki investasi dengan mengacu bidang usaha yang diprioritaskan pemerintah

5. Berkaitan dengan pengenaan sangksi, pelanggaran administrasi hanya dikenakan sanksi administrasi, sedangkan pelanggaran yang menimpulkan akibat K3L atau Keselamatan, Keamanan, dan Lingkungan akan dikenakan sanksi pidana (Rizal, 2021). 
Secara umum, peran UMKM dalam perekonomian bangsa ialah sebagai berikut (Sarfiah et al., 2019):

1. Sebagai pelaku utama dalam kegiatan ekonomi;

2. Penyedia lapangan kerja terbesar;

3. Pemeran penting dalam pengembangan perekonomian lokal dan pemberdayaan masyarakat;

4. Pencipta pasar baru dan sumber inovasi, serta

5. Kontribusinya terhadap neraca pembayaran.

Permasalahan umum yang dihadapi oleh sebagian besar pelaku UMKM adalah kurangnya SDM yang kompeten di bidangnya, lemahnya kreativitas dan inovasi, lemahnya kemampuan dalam membaca peluang yang ada, permodalan usaha, lemahnya strategi pemasaran, serta sistem networking yang juga lemah. Oleh karena itu perlu dukungan dari berbagai pihak dalam rangka penguatan UMKM melalui peningkatan sumber daya manusia (SDM). Sebagaimana disampaikan oleh Suyatno bahwa untuk dapat meningkatkan daya saing UMKM perlu meningkatkan kemampuan teknologi dan daya kreatif-inovatif sumber daya manusianya (Sarfiah et al., 2019). Sebaik apapun kualitas produk yang dihasilkan, seperti produk Batik Dewi Rengganis, namun minim promosi, maka ia tidak akan mampu bersaing di kancah nasional terlebih di pasar global.

Untuk menghadapi mekanisme pasar yang semakin terbuka dan kompetitif di tengah arus globalisasi, maka penguasaan pasar menjadi prasyarat utama guna meningkatkan daya saing UMKM. Oleh karena itu, penting bagi UMKM untuk mendapatkan informasi yang mudah dan cepat, baik informasi tentang pasar produksi maupun pasar faktor produksi. Informasi tentang pasar produksi sangat diperlukan untuk memperluas jaringan pemasaran produk yang dihasilkan oleh UMKM. Menurut Effendi Ishak informasi pasar produksi atau pasar komoditas yang diperlukan, misalnya berkaitan dengan (1) jenis barang yang dibutuhkan, (2) daya beli masyarakat, (3) harga pasar yang berlaku, (4) selera konsumen pada pasar lokal, regional maupun internasional. Sedangkan informasi pasar faktor produksi meliputi: (1) sumber bahan baku yang diperlukan, (2) harga bahan baku, (3) bagaimana memperoleh modal usaha, (4) siapa tenaga kerja yang professional, (5) tingkat upah atau gaji yang layak (Sarfiah et al., 2019). 
Selain itu, untuk dapat meningkatkan nilai jual UMKM itu sendiri, utamanya agar dapat bersaing dengan produk-produk lainnya, baik yang datang dari dalam negeri maupun dari luar negeri yang saat ini kian membanjiri sentra industri di Indonesia, maka UMKM perlu meningkatkan inovasi produk dan jasa, pengembangan sumber daya manusia dan teknologi, serta perluasan area pemasaran (Sedyastuti, 2018).

Oleh karena itu, strategi yang perlu dilakukan dalam rangka pengembangan UMKM untuk tetap dapat bertahan dan bersaing di pasar global adalah dengan peningkatan daya saing dan pengembangan sumber daya manusia diantaranya melalui penyaluran perkreditan (KUR), penyediaan akses informasi pemasaran, pelatihan lembaga keuangan mikro melalui capacity building, dan pengembangan information technology (IT), serta kampanye cinta produk dalam negeri (Sedyastuti, 2018).

Setelah mengetahui bagaimana cara meningkatkan dan mengembangkan UMKM di era sekarang, hal lain yang juga patut untuk dipahami dan disadari bersama adalah faktor-faktor yang menjadi penghambat daya saing ekonomi nasional, khususnya UMKM, baik pada tingkat lokal, nasional, maupun internasional. Beberapa faktor penghambat tersebut antara lain; korupsi, birokrasi yang tidak efektif dan efisien, infrastruktur yang kurang memadai, ketidakstabilan dunia politik, akses pada pembiayaan, tenaga kerja terdidik yang kurang memadai, etika kerja yang buruk, inflasi, kriminalitas, dan kesehatan yang secara umum masih bermasalah. Hal ini diperlukan upaya penanganan yang serius, utamanya dari pemerintah guna menjamin, melindungi, dan memberi kepastian hukum terhadap eksistensi UMKM di masa mendatang. Jika faktor-faktor penghambat tersebut dapat dibenahi dan diselesaikan dengan cepat, maka daya saing UMKM di Indonesia akan semakin meningkat

\section{Kesimpulan}

Dari paparan di atas dapat disimpulkan bahwa beberapa strategi yang selama ini dilakukan oleh UMKM Batik Dewi Rengganis guna meningkatkan ekonomi keluarga ialah dengan memberdayakan kaum perempuan, terutama ibu rumah tangga yang ada di sekitarnya, dengan tidak menutup akses kepada orang lain. Selain itu, UMKM Batik Dewi Rengganis juga selalu 
memiliki corak atau motif yang beragam dan menarik. Hal ini tentu menjadi nilai tersendiri bagi konsumen. Keunikan lainnya yang ada pada UMKM ini adalah selalu berkreativitas dan berinovasi, guna menjamin dan meningkatkan kualitas produknya. Meski telah memiliki beberapa keunggulan di mata masyarakat pecinta batik, namun terdapat beberapa hal yang masih perlu dibenahi, seperti kurangnya sumber daya manusia yang kompeten, minimnya penggunaan teknologi informasi, dan jaringan pemasaran yang kurang maksimal. Oleh karena itu, hal yang perlu ditingkatkan adalah bagaimana mengembangkan kemampuan sumber daya manusia dan teknologi dengan misalnya mengikutsertakan beberapa SDM yang ada dalam kegiatan-kegiatan pelatihan, penyuluhan, maupun workshop tentang batik dan teknologi informasi, serta menyediakan akses pemasaran yang memadai.

\section{Pengakuan}

Alhamdulillah, kami bersyukur atas terselenggaranya kegiatan pendampingan ini dalam rangka membentuk dan mewujudkan sektor usaha yang memiliki daya saing, baik di tingkat nasional maupun internasional. Terima kasih kami sampaikan kepada UMKM Batik Dewi Rengganis yang telah menfasilitasi kegiatan ini sehingga dapat terlaksana dengan sukses. Tim Pendamping juga banyak mengucapkan terima kasih kepada pihak LP3M Universitas Nurul Jadid yang senantiasa memberikan arahan selama proses kegiatan ini berlangsung.

\section{Referensi}

Apriyanti, M. E. (2018). Pentingnya Kemasan terhadap Penjualan Produk Perusahaan. Sosio E-Kons, 10(1), 20. https://doi.org/10.30998/sosioekons.v10i1.2223

Dewanti, R., Melati, I., \& Simbolon, F. (2013). Pengembangan Model Daya Saing UMKM Batik Melalui ECS. Binus Business Review, 4(1), 41. https://doi.org/10.21512/bbr.v4i1.1034

Kusumawardhani, R. T., \& Nurani, F. (2019). Peningkatan Pemberdayaan UMKM Kreatif Dalam Pembangunan Ekonomi Ideal Indonesia. 
http://blog.ub.ac.id/rezatitanika/files/2019/12/JURNAL-ADMPEMBANGUNAN.pdf

Mubyarto, Indonesia, \& Badan Perencanaan Pembangunan Nasional. (1996). Ekonomi rakyat dan program IDT. Diterbitkan untuk BAPPENAS oleh Aditya Medai.

Pranarka, A. M. W. (1996). Pemberdayaan Konsep, Kebijakan, dan Implementasi. Centre for Strategicand International Studies(CSIS).

Puput, P. (2017). Ingin Belajar Batik, Datanglah ke Galeri Batik Dewi Rengganis. beritalima.com. https://beritalima.com/ingin-belajarbatik-datanglah-ke-galeri-batik-dewi-rengganis/

Rizal, M. (2021). Pengaruh Uu Cipta Kerja (Omnibus Law) pada Kesejahteraan Pekerja Perempuan. Jurnal Sekretaris \& Administrasi Bisnis (JSAB), 5(2), 162. https://doi.org/10.31104/jsab.v5i2.231

Sarfiah, S., Atmaja, H., \& Verawati, D. (2019). UMKM Sebagai Pilar Membangun Ekonomi Bangsa. Jurnal REP (Riset Ekonomi Pembangunan), 4(2), 1-189. https://doi.org/10.31002/rep.v4i2.1952

Sari, N. K., \& Susanti, D. O. (2019). Perlindungan Hukum Bagi Pemilik Karya Cipta Batik Tulis Dewi Rengganis Di Desa Jatiurip Kecamatan Krejengan Kabupaten Probolinggo. SASI, 24(2), 124. https://doi.org/10.47268/sasi.v24i2.127

Sedyastuti, K. (2018). Analisis Pemberdayaan UMKM Dan Peningkatan Daya Saing Dalam Kancah Pasar Global. INOBIS: Jurnal Inovasi Bisnis Dan Manajemen Indonesia, 2(1), 117-127. https://doi.org/10.31842/jurnal-inobis.v2i1.65

Wati, D. K., Sukatman, \& Satrijono, H. (2013). Cerita Dewi Rengganis dalam Tradisi Lisan Masyarakat Probolinggo. Repository.Unej.Ac.Id. https://repository.unej.ac.id/handle/123456789/61735

Widyasari, N. (2018). Pemberdayaan perempuan dalam perspektif gender melalui home industry batik tulis Dewi Rengganis di Desa Jatiurip Kecamatan Krejengan Kabupaten Probolinggo [Universitas Negeri Malang]. http://repository.um.ac.id/55949/

Widyasari, N., Towaf, S. M., \& Eskasasnanda, I. D. P. (2021). Ibu rumah tangga dan peningkatan ekonomi keluarga: Pemberdayaan 
perempuan di Home Industry Batik Tulis Dewi Rengganis Kabupaten Probolinggo. Jurnal Integrasi Dan Harmoni Inovatif IImu-IImu Sosial, 1(1), 1-7. https://doi.org/10.17977/um063v1i1p1-7 